\title{
A Survey of pediatric anesthesia practice for magnetic resonance imaging in French hospitals
}

\begin{abstract}
Objective: To analyze pediatric anesthesia practice for magnetic resonance imaging (MRI) in France. General anesthesia in pediatrics for MRI is being more and more developed and is an activity that can present some risks. The only survey concerning this subject was published in 2007 by Bordes et al in the annales françaises d'anesthésie et de réanimation and concerned 25 university teaching hospitals in Metropolitan France. This present study aimed to investigate public and private hospitals.
\end{abstract}

Methods: Contact was taken with the Regional Health Agencies to have a list of all institutions authorized to realize magnetic resonance imaging in France. 432 centers were identified to which an anonymous questionnaire was sent by post.

Results: Among 432 centers reached by post, 143 responded. Among these, 31 practiced pediatric anesthesia. Of the 31 centers which practiced pediatric anesthesia one was a private institution, three were institutions participating to public health services, eight were general hospitals and nineteen were university teaching hospitals. The average duration time of the procedure was 30- 60 minutes for fourteen centers. General anesthesia was the technic of choice in twenty-six of centers.

Conclusion: In most centers, pediatric anesthesia practice for magnetic resonance was standardized and protocolized.

Keywords: french hospitals, pediatric anesthesia, magnetic resonance imaging
Volume 10 Issue 6 - 2018

\author{
Kumba C \\ Department of Pediatric Anesthesia and Critical Care, Necker \\ Sick Children's University Hospital, France
}

Correspondence: Kumba C, Department of Pediatric Anesthesia and Critical Care, Necker Sick Children's University Hospital, France, 149 Rue de Sèvres, 75015 Paris, France, Email claudene.kumba@gmail.com

Received: November 01, 2018 | Published: December 12, 2018

\section{Introduction}

Pediatric general anesthesia for magnetic resonance imaging (MRI) is being more and more developed and activity increasing about eight to nine percent per year. ${ }^{1}$ More than four thousand procedures per year were performed between 2004 and 2008 according to a study realised in the United States. ${ }^{1}$ The advantage of general anesthesia or sedation for MRI is to insure patient immobility and comfort during this procedure which can last between 30 and 90 minutes. Because of the situation outside the operation room and the presence of a high magnetic field, specific conditions must be respected in order to insure patient safety. For example personnel, induction and special MRI room equipment, postanesthesia care unit (PACU) and MRI compatible monitoring systems must be available. Ferromagnetic devices are prohibited because of the risk of projectiles, burns, interference with apparatuses like pacemakers and implantable defibrillators dislodgement. For all these reasons anesthesia for magnetic resonance imaging presents risks which can be minimised if all security conditions are respected in the same way as for anesthesia performed in the operating room. ${ }^{2-4}$ We aimed with this survey to analyse pediatric anesthesia practice for MRI in different public and private hospitals in France. The last survey was published in 2007 by Bordes et al and concerned only university teaching hospitals. ${ }^{5}$

\section{Methods}

In order to reach a great number of institutions we contacted the Regional Health Agencies (agencies in charge of organising Public Health at a regional level) which delivered us a list of 432 centers authorized to perform MRI in Metropolitan France and the overseas departments. We sent to these centers an anonymous questionnaire by post. The questionnaire concerned the type of centers i.e private, participating to public health services, general hospitals, university teaching hospitals; unspecialized centers (authorized to practise anesthesia in children above one year of age in elective surgery and above three years old in simple emergency surgery), specialised centers (were anesthesia can be realised in children under one year old with a pediatric intensive care unit available), reference centers (centers in charge of specific pathologies necessitating the presence of several pediatric specialists or a specialized pediatric intensive care unit). The questionnaire also investigated the total annual number of anesthesia according to age, airway control, ventilation, anesthetic technic and drugs, general organisation, personnel in charge and equipment. XLSTAT 2018.3 softwere was used for statistics. Variables are expressed in proportions.

\section{Results}

The results are presented in different figures and tables. Amoung 432 center reached, 143 responded to the survey. Figure 1 illustrates the distribution of 143 centers which responded; 31 practiced pediatric anesthesia, 112 did not practice pediatric anesthesia. Figure $2 \&$ Figure 3 illustrate the characteristics of the 31 centers which practiced pediatric anesthesia: the majority i.e., 19 of the 31 centers were university teaching hospitals and referenced centers. Tables 1 and 2 represent the total annual number of anesthesia and anesthesia according to age. In most centers (17/31), the annual total number of pediatric anesthesia was less than a thousand table 2. 26 centers amoung the 31 performed general anesthesia, Figure 4. Figure 5 shows the induction and maintenance of anesthesia. 25 and 22 of the 31 centers used sevoflurane for induction and maintenance of anesthesia respectively. 5 centers of 31 used propofol for induction and maintenance of anesthesia. Figure 6 represents airway control and ventilation, 19 of 31 centers used spontaneous ventilation and 12 of 31 used volume or pression control ventilation. Table 3 illustrates induction and MRI room equipment and postanesthetic care unit. Table 4 illustrates general organization. 
Table I Annual number of anesthesia according to age and the number of centers

\begin{tabular}{|c|c|c|c|c|c|}
\hline Annual number of ansthesia & $\begin{array}{l}\text { Children } \\
\text { under one } \\
\text { year old }\end{array}$ & $\begin{array}{l}\text { Children } \\
\text { between I-3 } \\
\text { years old }\end{array}$ & $\begin{array}{l}\text { Children } \\
\text { between 3-5 } \\
\text { years old }\end{array}$ & $\begin{array}{l}\text { Children } \\
\text { between 5-I0 } \\
\text { years old }\end{array}$ & $\begin{array}{l}\text { Children over } \\
10 \text { years old }\end{array}$ \\
\hline $\begin{array}{l}\text { Less than a hundred anesthesia per } \\
\text { year }\end{array}$ & $26 / 31$ centers & $25 / 3$ I centers & $26 / 3$ I centers & $27 / 31$ centers & $29 / 3$ I centers \\
\hline $\begin{array}{l}\text { More than a hundred anesthesia per } \\
\text { year }\end{array}$ & $5 / 31$ centers & $6 / 3$ I centers & $5 / 31$ centers & $4 / 3$ I centers & $2 / 31$ centers \\
\hline Total & $3|/ 3|$ centers & $3|/ 3|$ centers & $3|/ 3|$ centers & $3|/ 3|$ centers & $3|/ 3|$ centers \\
\hline
\end{tabular}

Table 2 Annual number of anesthesia according to age

\begin{tabular}{lll}
$\begin{array}{l}\text { Less than } 1000 \text { pediatric anesthesia } \\
\text { per year }\end{array}$ & $\begin{array}{l}\text { Between } 1000-5000 \text { pediatric } \\
\text { anesthesia per year }\end{array}$ & $\begin{array}{l}\text { Between } 5000-10000 \text { pediatric } \\
\text { anesthesia per year }\end{array}$ \\
\hline$|7 / 3|$ centers & $10 / 3 \mid$ centers & $4 / 3 \mid$ centers \\
\hline
\end{tabular}

Table 3 Illustrâtes induction and MRI rooms equipment and postanesthetic care unit, ECG, electrocardiogram; NIBP, non invasive blood pressure; SPO2, pulse oximetry

\begin{tabular}{|c|c|c|c|c|}
\hline Induction room & I place $(29 / 3 I)$ & 2 places $(I / 3 I)$ & 3 places $(I / 3 I)$ & \\
\hline $\begin{array}{l}\text { PACU (postanesthesia care } \\
\text { unit) }\end{array}$ & $\begin{array}{l}\text { Next to the MRI } \\
\text { room }(10 / 3 I)\end{array}$ & $\begin{array}{l}\text { Near the MRI room, where } \\
\text { the patient is transfered after } \\
\text { recovery from anesthesia }(I 3 / 3 \mid)\end{array}$ & $\begin{array}{l}\text { Far from the MRI room, } \\
\text { where the patient is } \\
\text { transfered after recovery } \\
\text { from anesthesia }(8 / 3 I)\end{array}$ & \\
\hline $\begin{array}{l}\text { Duration of the } \\
\text { postanesthesia care }\end{array}$ & $\begin{array}{l}\text { Less than } 30 \text { minutes } \\
(|7 / 3|)\end{array}$ & More than 30 minutes $(|4 / 3|)$ & & \\
\hline Specific pediatric PACU & Yes $(|4 / 3|)$ & No $(|7 / 3|)$ & & \\
\hline $\begin{array}{l}\text { Specific pediatric one day } \\
\text { unit }\end{array}$ & Yes $(19 / 31)$ & $\begin{array}{l}\text { No (one day unit not specific for } \\
\text { pediatrics) }(8 / 31)\end{array}$ & $\begin{array}{l}\text { No (standard } \\
\text { hospitalisation unit) }(4 / 31)\end{array}$ & \\
\hline $\begin{array}{l}\text { Magnetic resonance imaging } \\
\text { (MRI) system }\end{array}$ & I,5 Tesla $(24 / 3$ I) & 3 Tesla $(7 / 3 I)$ & & \\
\hline Induction room equipment & $\begin{array}{l}\text { Permanent } \\
\text { monitoring system, } \\
\text { ventilator and } \\
\text { anesthesia cart } \\
(24 / 31)\end{array}$ & $\begin{array}{l}\text { Permanent monitoring system and } \\
\text { ventilator and a mobile anesthesia } \\
\text { cart }(4 / 3 I)\end{array}$ & $\begin{array}{l}\text { All the equipment is } \\
\text { mobile }(3 / 31)\end{array}$ & \\
\hline Surveillance camera & Yes $(25 / 31)$ & No $(6 / 31)$ & & \\
\hline Monitoring system & $\begin{array}{l}\text { MRI compatible } \\
\text { ECG,capnography, } \\
\text { SPO2, NIBP }(2 \mid / 3 I)\end{array}$ & $\begin{array}{l}\text { MRI compatible } \\
\text { ECG,capnography,NIBP,SPO2 } \\
\text { thermometer }(3 / 31)\end{array}$ & $\begin{array}{l}\text { MRI compatible ECG,SPO2 } \\
\text { Capnography }(6 / 3 I)\end{array}$ & $\begin{array}{l}\text { MRI } \\
\text { compatible } \\
\text { ECG ,SPO2 } \\
(I / 3 I)\end{array}$ \\
\hline MRI compatible Ventilator & Yes $(29 / 31)$ & No $(I / 3 I)$ & No ventilator $(I / 3 \mid)$ & \\
\hline $\begin{array}{l}\text { Minimal tidal volume } \\
\text { delivered by the ventilator }\end{array}$ & $30 \mathrm{ml}(20 / 3 \mathrm{l})$ & $50 \mathrm{ml}(7 / 3 \mathrm{l})$ & More than $100 \mathrm{ml}(4 / 3 \mathrm{I})$ & \\
\hline
\end{tabular}

Table 4 Organisation

\begin{tabular}{|c|c|c|c|c|}
\hline $\begin{array}{l}\text { Anesthesiologists in } \\
\text { charge of the MRI } \\
\text { activity }\end{array}$ & $\begin{array}{l}\text { Pediatric } \\
\text { anesthesiologists } \\
\text { exclusively in charge of } \\
\text { MRI activity }(7 / 31)\end{array}$ & $\begin{array}{l}\text { Pediatric } \\
\text { anesthesiologists not } \\
\text { exclusively in charge } \\
\text { of the MRI activity } \\
(5 / 3 I)\end{array}$ & $\begin{array}{l}\text { Pediatric } \\
\text { anesthesiologists } \\
\text { and general } \\
\text { anesthesiologists } \\
(5 / 3 I)\end{array}$ & $\begin{array}{l}\text { General } \\
\text { anesthesiologists } \\
\text { not exclusively } \\
\text { in charge of MRI } \\
\text { activity }(14 / 3 I)\end{array}$ \\
\hline The team in charge & $\begin{array}{l}\text { Nurse anesthesist alone or } \\
\text { anesthesiologist alone }(2 / 31)\end{array}$ & $\begin{array}{l}\text { Nurse anesthesist with } \\
\text { anesthesiologist }(23 / 31)\end{array}$ & $\begin{array}{l}\text { Others (radiologist or } \\
\text { pediatric doctor) }(6 / 31)\end{array}$ & \\
\hline $\begin{array}{l}\text { Participation of } \\
\text { anesthesiology } \\
\text { postgraduates }\end{array}$ & Yes $(16 / 31)$ & No (15/3I) & & \\
\hline $\begin{array}{l}\text { Systematic anesthesia } \\
\text { consultation few days before }\end{array}$ & Yes $(3|/ 3|)$ & & & \\
\hline
\end{tabular}




\begin{tabular}{|c|c|c|c|c|}
\hline $\begin{array}{l}\text { Anesthesiologists in } \\
\text { charge of the MRI } \\
\text { activity }\end{array}$ & $\begin{array}{l}\text { Pediatric } \\
\text { anesthesiologists } \\
\text { exclusively in charge of } \\
\text { MRI activity (7/3I) }\end{array}$ & $\begin{array}{l}\text { Pediatric } \\
\text { anesthesiologists not } \\
\text { exclusively in charge } \\
\text { of the MRI activity } \\
(5 / 3 I)\end{array}$ & $\begin{array}{l}\text { Pediatric } \\
\text { anesthesiologists } \\
\text { and general } \\
\text { anesthesiologists } \\
(5 / 3 I)\end{array}$ & $\begin{array}{l}\text { General } \\
\text { anesthesiologists } \\
\text { not exclusively } \\
\text { in charge of MRI } \\
\text { activity (I } / 4 / 3 I)\end{array}$ \\
\hline $\begin{array}{l}\text { Parents' presence at } \\
\text { induction of anesthesia }\end{array}$ & Yes $(19 / 31)$ & Non (I2/3I) & & \\
\hline $\begin{array}{l}\text { Premedication in case of } \\
\text { general anesthesia }\end{array}$ & No premedication $(\mathrm{I} \mid / 3 \mathrm{I})$ & $\begin{array}{l}\text { Premedication with oral } \\
\text { benzodiazepine }(9 / 31)\end{array}$ & $\begin{array}{l}\text { Premedication with } \\
\text { intrarectal benzodiazepine } \\
(8 / 31)\end{array}$ & $\begin{array}{l}\text { Premedication with } \\
\text { hydroxyzine }(3 / 31)\end{array}$ \\
\hline Peripheral venous catheter & Systematic $(29 / 3 \mathrm{I})$ & Sometimes $(2 / 3 \mathrm{I})$ & & \\
\hline $\begin{array}{l}\text { Duration time of the } \\
\text { procedure (MRI) }\end{array}$ & $15-30$ minutes $(10 / 31)$ & $30-60$ minutes $(|8 / 3|)$ & $60-90$ minutes $3 / 31$ ) & \\
\hline $\begin{array}{l}\text { Number of children taken in } \\
\text { charge per half a day }\end{array}$ & Less than five $(19 / 31)$ & More than five $(12 / 3 \mid)$ & & \\
\hline
\end{tabular}

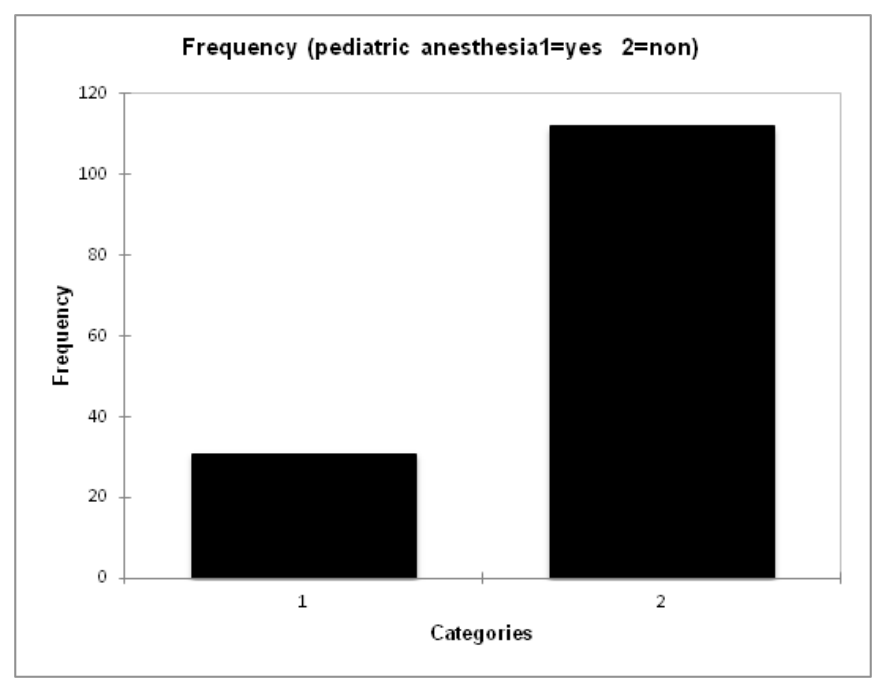

Figure I Pediatric anesthesia practice

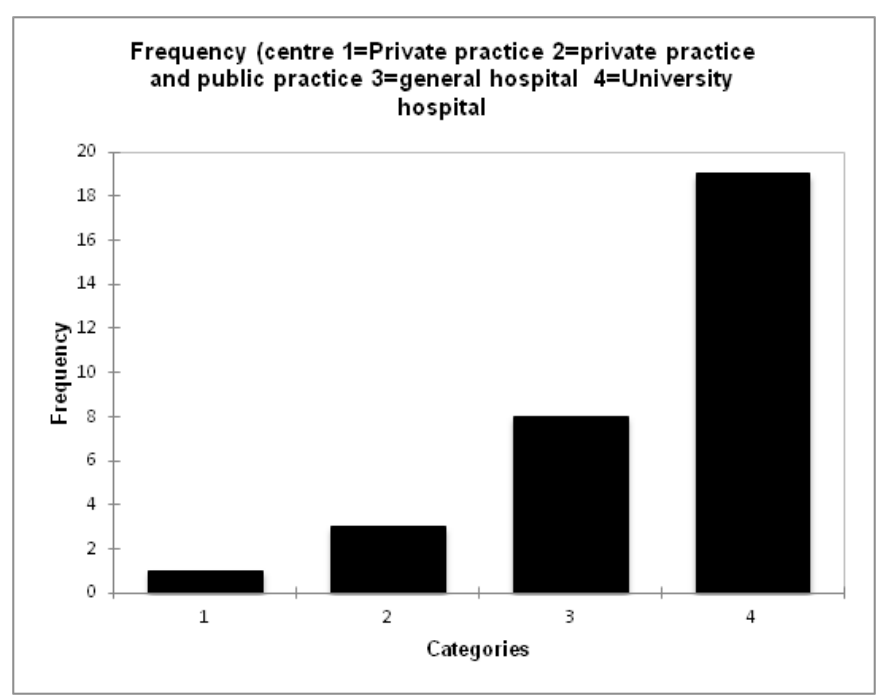

Figure 2 Type of practice

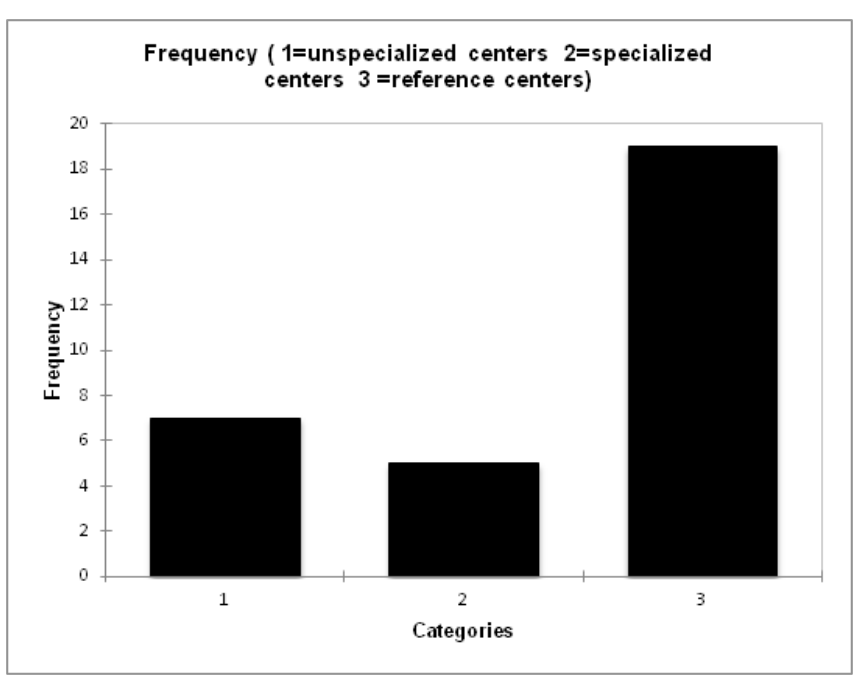

Figure 3 Specificity

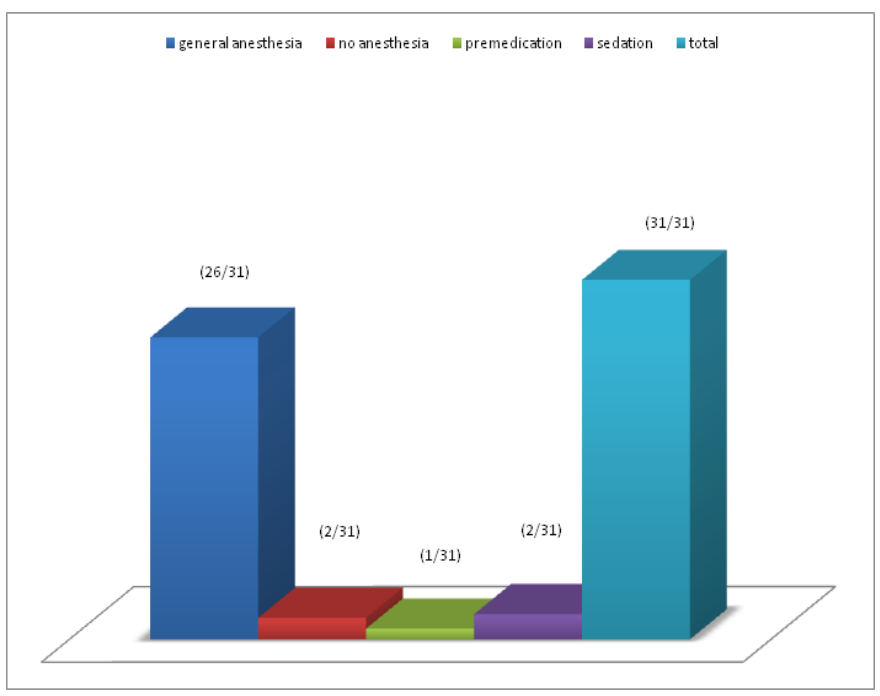

Figure 4 Anesthetic technic of choice 


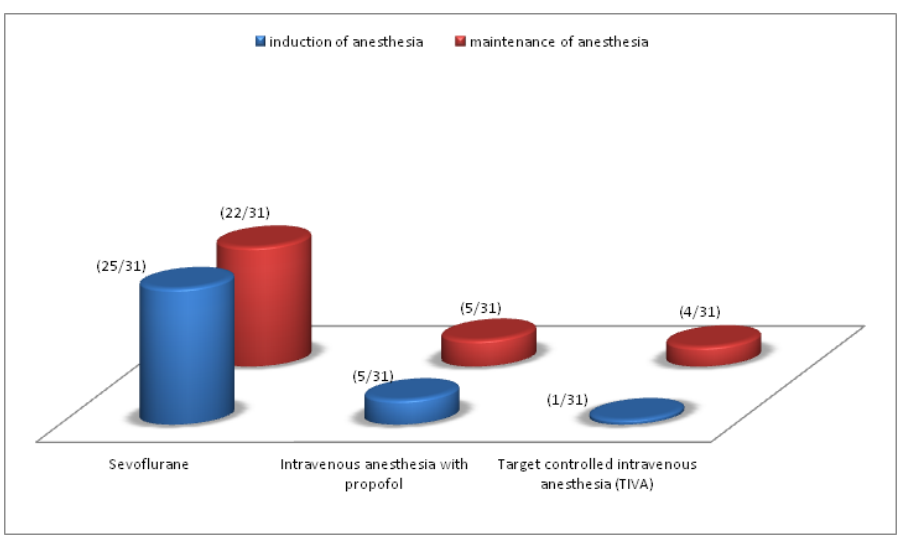

Figure 5 Induction and maintenance of anesthesia

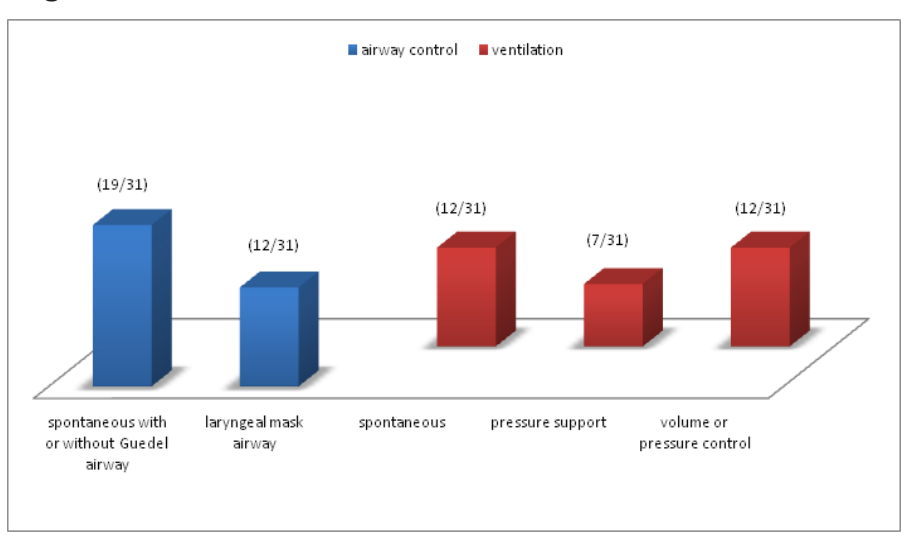

Figure 6 Airway control and ventilation

\section{Discussion}

This survey concerned private and public centers ( 31 in total), of which 19 wer university teaching hospitals and referenced centers. In the 2007 survey, only university teaching hospitals were implicated (25 in total). The anesthetic activity for MRI was performed by pediatric anesthesiologists in $39 \%$ of the centers in our survey and in $80 \%$ of centers in the Bordes et al survey and this can be explained by the fact that their study only investigated university teaching hoaspitals. In a similar survey conducted in Canada in university teaching hospitals, pediatric anesthesiologists were in charge of this activity. ${ }^{6}$ The mean duration time of the procedure was between 30 and 60 minutes according to the part of the body explored, which corresponds to what is described in the literature..$^{2,3,7}$

General anesthesia was realised in most centers with sevoflurane being the agent of choice for induction and maintenance of anesthesia in our survey as it was reported in the 2007 survey. In the Canadian survey propofol was the drug of choice. ${ }^{6}$ Inhalational agents are widely used. ${ }^{3}$ A prospective randomised study in more than eighty children compared sevoflurane and propofol and concluded to a rapid induction, rapid recovery and more emergence agitation with sevoflurane. ${ }^{8}$ The emergence agitation induced by sevoflurane can be reduced by administering a bolus of propofol at the end anesthesia. ${ }^{9}$ Spontaneous ventilation with or without Guedel airway was used in $61 \%$ of centers in our study and $20 \%$ in the 2007 study; the laryngeal mask airway was used in $39 \%$ of cases in this survey and $20 \%$ in the
Bordes et al survey; there was no intubation in our survey whereas in the 2007 survey $36 \%$ centers realised intubation. This can influence the duration time of the procedure. A retrospective study reported the duration time of anesthesia as varying between six minutes if spontaneous ventilation was used ( without laryngeal mask airway or intubation) to twenty minutes in case of intubation. ${ }^{10}$ Another prospective study in more than two hundred children admitted for MRI, evaluated the hospitalisation time (time spent between admission and returning home) and the cost generated. The hospitalisation time was 2 hours and 21 minutes for the children without general anesthesia, 3 hours and 36 minutes in the group of sedation and 4 hours and 7 minutes in the general anesthesia group.

The cost was higher in the general anesthesia group. ${ }^{11}$ One other retrospective study in more than four hundred pediatric patients who underwent sedation or general anesthesia for MRI, concluded to a benefit/risk ratio which was higher in the general anesthesia group. There were more side effects with sedation (in terms of emesis and hypoxemia). ${ }^{12}$ In a prospective study concerning more than a thousand children admitted for MRI also reported more hypoxemia when sedation was used. ${ }^{13}$ In 17 of centers there was no specific pediatric postanesthestic care unit (PACU) and 14 of the centers had a specific pediatric PACU. Emergence agitation is common after pediatric anesthesia and can be influenced by identifiable factors and necessitate increased care and time. ${ }^{14,15}$ Parents' presence in the PACU reduces behavior disorders that can be observed up to two weeks after anesthesia, as it was demonstrated in a prospective randomised trial in three hundred children. ${ }^{16}$ This survey had limits : information about the hospitalisation duration time and cost as well as the side effects in relation with the anesthetic technic were not evaluated.

\section{Conclusion}

According to our survey, in the majority of centers investigated the organization and the equipment settings for pediatric anesthesia for MRI were standardized, and protocolized. The data analysis concerned 31 centers practicing pediatric anesthesia.

\section{Declarations}

Since this was an anonymous survey, approval from the local Ethics Committee was not necessary.

\section{Funding}

There was no funding.

\section{Acknowledgment}

The author contributed in collecting, analysing data, writing and reviewing this article.

\section{Conflicts of interest}

Author declares that there is no conflict of interest.

\section{References}

1) Wachtel RE, Dexter F, Dow AJ. Growth Rates in Pediatric Diagnostic Imaging and Sedation. Anesth Analg. 2009;108(5):1616-1621.

2) Decree-law $n^{\circ}$ 94-1050 of 5 December 1994 relating the operating technical conditions of health institutions with regard to practice of anesthesia and modifying the Code of public Health. 
3) Serafini G, Ongaro L, Mori A, et al. Anesthesia for MRI in the pediatric patient. Minerva Anestesiol. 2005;71(6):361-366.

4) Cox RG, Levy R, Hamilton MG, et al. Anesthesia can be safely provided for children in a high-field intraoperative magnetic resonance imaging environment. Paediatr Anaesth. 2011;21(4):454-458.

5) Bordes M, Semjen F, Sautereau A, et al. Which anaesthesia for children undergoing MRI ? An internet survey in French university hospitals. Ann Fr Anesth Réanim. 2007;26(4):287-291.

6) Usher A, Kearney R. Anesthesia for magnetic resonance imaging in children: a survey of Canadian pediatric centres. Can J Anaesth. 2003;50:425.

7) Desoutter E. MRI under general anaesthesia in paediatric patients: organization. Ann Fr Anesth Réanim. 2010; 29:557-559.

8) Kol IO, Egilmez H, Kaygusuz K, et al. Open-label, prospective, randomized comparison of propofol and sevoflurane for laryngeal mask anesthesia for magnetic resonance imaging in pediatric patients. Clin Ther. 2008;30(1):175-181.

9) Abu-Shahwan I. Effect of propofol on emergence behavior in children after sevoflurane general anesthesia. Paediatr Anaesth. 2008;18(1):5559.

10) Heinrich $S$, Irouschek A, Ackermann A, et al. Anesthesiological time requirements and reasons for delayed processes in MRI examinations of children undergoing sedation or general anesthesia. Rofo. 2013;185(5):467-473.
11) Vanderby SA, Babyn PS, Carter MW, et al. Effect of anesthesia and sedation on pediatric MR imaging patient flow. Radiology. 2010;256(1):229-237.

12) Sammons HM, Edwards J, Rushby R, et al. General anaesthesia or sedation for paediatric neuroimaging: current practice in a teaching hospital. Arch Dis Child. 2011;96(1):114.

13) Malviya S, Voepel-Lewis T, Eldevik OP, et al. Sedation and general anaesthesia in children undergoing MRI and CT: adverse events and outcomes. Br J Anaesth. 2000 ;84:743-748.

14) Maclaren Chorney J, Tan ET, Kain ZN. Adult-child interactions in the postanesthesia care unit. Anesthesiology. 2013;118(4):834-841.

15) Voepel-Lewis T, Malviya S, Tait AR. A prospective cohort study of emergence agitation in the pediatric postanesthesia care unit. Anesth Analg. 2003;96(6):1625-1630.

16) Lardener DR, Dick BD, Crawford S. The effects of parental presence in the postanesthetic care unit on children's postoperative behavior: a prospective, randomized, controlled study. Anesth Analg. 2010;110(4):1102-1108. 